\title{
The Art of Fugue: Heidegger on Rhythm
}

\author{
David Nowell-Smith
}

During his short lecture on Stefan George's "Das Wort," Heidegger turns to another of George's "songs," "In stillste ruh." After reading the poem aloud, he offers the following "short remark:"

The rhythm of this song is as marvellous as it is clear. It is enough to suggest it with a short remark. Rhythm, rhuthmos, does not mean flux and flowing, but rather structure [Fügung]. Rhythm is what is at rest, what structures [fügt $]$ the movement $[$ Be-wegung] of dance and song, and thus lets it rest within itself. Rhythm bestows rest. In the song we just heard, the structure shows itself if we pay heed to the one fugue [Fuge] which sings to us, in three forms, in three stanzas: secure soul and sudden sight, stem and storm, sea and shell. ${ }^{1}$

Rhythm, removed both from its literary critical usage and from the philosophical tradition that has interpreted it as "flux," would, through its close working of the cognates of fügen, trace the movedness of being. But the particular rhythm through which this movedness becomes discernable is the "fugue" [Fuge $]$ of the poem itself. This invites the question - how does the rhythm that issues from the movement and rest of being interact with "poetic" rhythm more broadly?

This is the question that the current essay will pose; in so doing it will return to that vexed issue of Heidegger's disregard for literary criticism. The rhythm Heidegger outlines in his discussion of George is far removed from "rhythm" as literary critics would envisage it: the

Gatherings: The Heidegger Circle Annual, 2 (2012): 41-64, 
patterning of the "suprasegmentals" of speech (which, for purposes of disambiguation, I will henceforth term "prosody"). Indeed, he situates the poem's "rhythm" in its tropological development, from "secure soul" to "sea and shell;" what literary critics would call rhythm is pointedly absent. Elsewhere he is more explicit in this regard. The discussion of Georg Trakl's "Ein Winterabend" begins with the laconic remark: "Meter and rhyme pattern can be defined accurately according to the schemes of metrics and poetics," but such "schemes" leave us "confined by the notion of language that has prevailed for thousands of years."2 The metrical patterning of the sounds of language independently of their sense treats language as a semantic content transmitted through sensuous tokens, whereas Heidegger would refigure verbal language as a "sounding" anterior to the sound-sense split. ${ }^{3}$ And in the 1953 lecture on "Language in the Poem," again on Trakl, he says that the "site of the poem [Gedicht], as the source of the animating wave [bewegende Woge], holds within it the veiled essence of what - to metaphysicalaesthetic representation - can at best appear as rhythm."4 "Rhythm" (i.e. prosody) is a metaphysical-aesthetic derivation of the animating wave that sets language itself into motion.

Heidegger's choice of Fuge to describe George's poem is particularly intriguing: it is a well-known musical form, but also alludes to what he elsewhere thematizes as the "jointure" of beings in presence. It offers a point of contact between the poem's formal palette and its claim to disclose the shape of the presencing of beings as a whole. The following pages will probe Fuge as it is deployed to understand the peculiar temporality of beings in their presencing, but also as it describes the way an artwork coheres and the "unifying element" by which verbal language and the disclosive "gathering" are bound together in the "saying" [Sage] of language. Poetry comes to be conceived by Heidegger as a kind of threshold between two modes of rhythmicity: the oscillations between presencing and absencing on the one hand, and prosody on the other. In the final section I will ask how these two different experiences of rhythm intersect - are "joined," even - in Heidegger's readings of poetry. 
FUGE: JOINTURE AND FUGUE

In the second section of Being and Time, Heidegger proposes not simply that being is temporal, but that time $i s$ being. But to substantiate this claim requires that we reconceive of both "being" (which is no longer a transcendental substrate, "big Being," but rather the shape of beings' disclosing themselves "in their being") and "time." Time had been portrayed by philosophers from Aristotle to Hegel as a series of discrete "nows." For Heidegger it is that movement through which what appears "now" emerges from out of, and withdraws into, the double absence of its having-been [Gewesenheit] and its futurity [Zukünftigkeit]. ${ }^{6}$

When Heidegger discusses rhuthmos itself, in the 1939 lecture on Aristotle's Physics, the concern remains that of the temporal character of beings' self-disclosure. Heidegger translates rhuthmos as "articulating, impressing, fitting, and forming": Gliederung, Prägung, Fügung, und Verfassung. ${ }^{7}$ Offering "articulation" as a possible translation recalls the discussion of language in Being and Time, where "discourse is the articulation of intelligibility": in one gesture it binds entities together in an intelligible whole and differentiates them, both synthesis and diairesis. ${ }^{8}$ In translating rhuthmos as Fügung (translated by Sheehan as "fitting"), Heidegger anticipates the account of rhythm we saw in his discussion of George's "In stillste ruh."

The initial concern in the discussion of rhuthmos in the Aristotle lecture is Antiphon's claim that the proton arruthmiston, that which is untouched by the temporality of appearance, is what is "most being" (even if, for precisely this reason, what is "most being" will never enter presence). Aristotle, Heidegger argues, inverts this: rhuthmos does not describe entities that appear temporally, but rather indicates the temporal structure by which the entity remains within appearance as bounded by the absences of non-being. It is only in rhuthmos that a being can articulate itself, that is, set itself into relation with its surrounds, and take an intelligible form - and thus be said "to be." For Antiphon, what is "most being" cannot admit of a change of state, as this would amount to saying that its being is incomplete; yet if "to be" means "to enter into presence," then what is most-being must continually be in 
movement if it is to remain in being. Rhuthmos is not flux, instability, but rather that which structures a being's appearance within time, that which allows it to enter into presence as an intelligible "such-and-such" that we can encounter in an "open" region.

Heidegger attempts to grasp something similar in his gloss of dike in "Anaximander's Saying." In place of the standard translations of dike as "penalty" or "damages," Heidegger turns to another cognate of fügen: "dike, thought out of being as presencing, is the ordering, jointure-giving order [fugend-fügende Fug]." ${ }^{9}$ In order for beings to enter into presence, they must be "joined" in such a way that they are intelligible and, for Heidegger, this jointure is paradigmatically temporal, adjoining "all that presences between a twofold absence (arrival and departure)." All jointure, Heidegger stipulates, is a "jointure of the while."10

Here too Heidegger is building on Being and Time's exposition of the three temporal ecstases. Just as the presencing of beings cannot be situated in a discrete series of "nows," Heidegger distinguishes the "while" from mere "continuation." However, Heidegger sees Anaximander's fragment to stage a contest between these two conceptions of time. As an entity attempts to persist in presence, it "concerns itself no longer with the other things that are present" and so "stands in dis-jointure" [in der Un-Fuge]: it presences "without and against the jointure of the while." 11 In dis-jointure, presence is no longer a "while" bounded by a double absence, but rather "continuation": what will later be conceptualized by Plato as "constant presence." This "metaphysical" interpretation of presencing as constant presence is, then, already latent in Anaximander's fragment; but for Anaximander, Heidegger argues, dis-jointure becomes the mode in which the being in fact "gives jointure." In other words, the being's resistance to its temporal finitude becomes the mode through which it inhabits time as a finite being.

In the glosses of both rhuthmos and dike, then, Heidegger offers an account of how beings constitute themselves temporally through their engagement with absence; both take issue with the conception of time in which what is "most being" is characterized by "constant presence." Central to this argument is the claim that the division of 
time into discrete units transforms the basic fact that we encounter the auto-disclosure of entities temporally into an insurmountable enigma; the intelligibility of the world is put "out of joint." This argument recurs throughout Heidegger's work, not simply in discussions of temporality but also regarding any attempt to break the meaningful fabric of experience down into "sense data." In Being and Time he says: "Initially' we never hear noises and complexes of sound, but the creaking wagon, the motorcycle. We hear the column on the march, the north wind, the woodpecker tapping, the crackling fire." ${ }^{12}$ In The Principle of Reason, thirty years later, he revisits this argument: "Of course we hear a Bach fugue with our ears, but if we leave what is heard only at this, with what strikes the tympanum as sound waves, then we can never hear a Bach fugue." "13 Just as Bach's fugue cannot be broken down into its constituent parts and remain the artwork that it is, so the fugal "jointure" of beings within the while cannot be divided into a series of discrete "nows."

Given Heidegger's employment of the term Fuge as "jointure" from the 1930s onwards, it is quite striking that he should have chosen a fugue as his example of meaningful sound irreducible to a configuration of auditory data. This is even more the case when we think that one year after The Principle of Reason he will describe "In stillste ruh" as a "fugue." In the George lecture, Fuge as musical form and Fuge as jointure are quite explicitly aligned, as George's "fugue" joins the three stanzas into a "rhythmic" unity. Without lapsing into etymological opportunism, I would like to pursue exactly what is taking place when Heidegger aligns the "jointure" of beings in presence with this intricate form of musical composition.

In a fugue, one motif (the subject) is developed polyphonically, undergoing a series of inversions and modulations, changes of register and timbre, but always guided and bounded by a strict forward motion. Each time the subject returns in a new melodic strand (a voice), undergoing inversions and modulations, it is at once linked to and differentiated from every other voice within the polyphony; moreover, each voice, as it enters into the fugue's polyphonic fabric, advertises 
its own entry into audibility and at the same time advertises it as an entry out of absence. It is notable in this regard that the subjects of most of Bach's fugues took extended upbeats as their starting point, as though to perform its movement from silence towards the cadence that would signal its "arrival." And, within the fugue's broader structure, the subject's movement from absence into presence, and its recurrence in differing forms, cuts against the forward propulsion of the fugue as a whole, so as to create a highly wrought temporal frame. Without this forward propulsion the counterpoint of these different voices would lose its intricacy; without the counterpoint, the forward propulsion loses its urgency.

But this would suggest that the fugue offers two opposed experiences of time: the metronomic rhythm of the time signature and tempo, and the fugal rhythm of the plays of similarity and difference involved in the polyphony itself. It is not simply the different voices that are in counterpoint in a fugue, but these two conceptions of time. Might we find something similar in Heidegger's own analyses of poetic rhythm, and between the rhythmicity of beings' entry into appearance on the one hand, and the poems' prosodic patterning on the other? Before offering a response to this question, I wish to probe the way that movement is thematized in Heidegger's accounts of the artwork and of language, which, we shall see, meet in his readings of poetry. The notion of a fugal "jointure" is central to how he conceives of the "agitated stillness" of the artwork, and of the "way-making movement" through which the "saying" of language enters into "speech."

\section{THE MOVEDNESS OF THE ARTWORK}

In the reading of "In stillste ruh", we learn of the "rest" of rhythm insofar as it structures the movement around it. Here Heidegger is drawing on his account of the "rest" or "repose" that in "The Origin of the Work of Art" characterises the artwork itself. The temple at Paestum attains its "unity" and "self-sufficiency" by virtue of "the closed, unitary repose of [its] resting-in-itself." ${ }^{\text {"14 }}$ Moreover, it is because the work is "solitary," because it "stands within itself" and "cuts all 
ties with human beings" that it can constitute a "step into the open," through which it "carries us into this openness and, at the same time, out of the realm of the usual."15 The artwork's hermetic stillness is the way that we can encounter it as a "happening of truth." Indeed, only by exhibiting such stillness can it transform our encounter with beings (or, in Heidegger's terminology, "set up a world"). For both the reading of "In stillste ruh" and "Origin," this rest, far from constituting the mere absence of motion, indicates "a state of extreme agitation [Bewegtheit]." In "Origin" this state of agitation is ascribed to a series of anterior movements, the "strife" of world and earth, and the countermovements of concealing and unconcealing, absencing and presencing. If the agitated stillness of the work structures the motion around it, it is because it renders manifest the oscillations between presencing and absencing through which movement as such becomes discernible.

Yet for Heidegger, the artwork does not indicate the dynamics of the strife of world and earth so much as instigate it. This happens through the artwork's treatment of the "earth" of its "work-material" (that is, its medium). As a "coming-forth concealing" movement, the "earth" functions as a limit inherent in the medium, conditioning the way this medium can appear within the world of phenomenal experience. ${ }^{17}$ As the artwork searches out the limits of its medium, the shape of the earth's "concealing" is modified, and with it the modalities of the medium's self-disclosure (its "coming-forth") are transformed. For as long as the artwork is at work, the shape of the earth-world relation continues to shift, continually breaching and reconfiguring its own limits, and with it the limits of beings' self-disclosure as such. This engagement with the limits and the concealing movement inhering in the medium Heidegger terms a "continually self-surpassing gathering;" " this allusion towards the revelatory function of logos is central to the model of the artwork Heidegger wishes to propose. Addressing entities "as" such-and-such within the work (through its depiction, for instance), and presenting itself "as" such-and-such (namely, as the work that it is), the work at the same time exceeds the very "as"structure of this address. 
In this, Heidegger points to a constitutive excess within logos itself: the work's ability to "gather" entities into openness depends on its exceeding the bounds of the open itself. ${ }^{19}$ The artwork, as a mode of logos, continually "strives" to grasp that which recedes into the work-material out of which it is fashioned, so as to "gather" beings into presence.

This is developed in the discussion of the artwork's Gestalt: its "figure" or singular "look." 20 As the work searches out the limits of its work-material, the earth, which, "bearing and rising up, strives to preserve its closedness," 21 is "wrested" into the world from which it would withdraw. The strife of world and earth is internalized into the artwork's engagement with its medium as a "contest of measure and limit," where the repertoire of means and techniques an art form has at its disposal confronts a medium that will resist these techniques. As the work contests the limits of its measure, it reflects on this measure, and comes to sketch out and to render manifest this contest itself. This is as much at work in the painterly perspective of cinquecento Florentine painting, which continually probes and questions its own illusory techniques, as it is in Manet's dismantling of perspective through pointedly incongruous spatial relations of figures, or Cézanne's attempt to evoke depth through shading and texture rather than through line; it is as much at issue in the unsettling effect of placing a caesura after the eighth syllable in a heroic line in $18^{\text {th }}$ century English verse, as it is in the typographical explosion of Mallarmé's Un coup de dés. In each instance, the opposing movements of "gathering" and "self-surpassing" are held together in a continual tension; in each instance this tension is figured as a "contest of measure and limit."

It is this contest which permits the strife to sketch itself out in a singular fashion, in what Heidegger calls the "rift-design" (Ri $\beta)$, and to embody this "rift-design" in the way the work shows itself as a singular configuration of this rift-design: its Gestalt. If the strife of world and earth is "fixed in place" in the Gestalt, it must not be stabilized or it will lose its strife-character and the work will cease to be "at work." It is in order to explain how it can fix this strife in place without subjecting to stasis that Heidegger specifies: "What is here called figure [Gestalt] is 
the structure [Gefüge] as which the rift joins itself $[\operatorname{der} R i \beta$ sich fügt $]$. This joined rift [gefügte Ri $\beta]$ is the jointure [Fuge] of the shining of truth." ${ }^{22}$ As the way in which the strife of world and earth remains continually in strife, and thereby binds together the "appearance" or "shining" [Scheinen] of truth, it is a movement of a movement, the articulation of an articulation. Attending to the ways in which the artwork is constituted by these different movements will allow us to attend to the "movedness" of the open as such, as it inflects the presencing of beings and the broader oscillations of presence and absence that shape of our encounter with these beings, what Sheehan astutely terms their "kinetic intelligibility."23

To see how this "movedness" or "agitation" [Bewegtheit $]$ inflects the artwork's Gestalt more concretely, an example may help. In Cézanne's Portrait dujardinier Vallier, the arching of the gardener's shoulders and the thickly applied downward brushstrokes of blacks and dark greens that make up his coat and waistcoat serve to engender an extraordinary sense of weight. ${ }^{24}$ Set firmly at the centre of the composition, this weight serves as a kind of organizing principle for the painting, drawing the various other textural movements towards a focal point. In addition to being a formal feature, this weight is central to the characterization of the painting's subject. As the focal point of the portrait is displaced from Vallier's face to his shoulders, we intimate his humility and fatigue; as he assumes the painting's compositional weight, he is endowed with a pathos of dignity and understated strength. But what is particularly striking is how, as the point at which the countermovements of brushstrokes cohere, Vallier himself becomes uncannily still - indeed, this stillness is one of the first things that strikes one when one encounters the work. It would seem to accord with what Heidegger identified as that "repose which is an inner concentration of motion, hence a highest state of agitation." 25

It is precisely this inner concentration of motion that Heidegger, in an ekphrastic poem about the Vallier portrait written in 1970, approaches as a Gestalt: 
Das nachdenksam Gelassens, das inständig

Stille der Gestalt des alten Gärtners

Vallier...

The reflective released, the standing-within

Stillness of the figure of old gardener

Vallier... ${ }^{26}$

The "inständig / Stille der Gestalt" evokes a stillness born of, and borne by, movement, in which the movement itself is figured, becomes figure. It is worth noting here that Gestalt has two senses within Heidegger's account of the artwork. It can either be the look of the artwork as a whole, its composition, or it can indicate a particular figure within the work - as in this instance, where the "figure" is that of Vallier himself. The shape of thinking is the same for both uses of Gestalt: it serves as a point of coherence in which the work's "agitated" crisscrossing of movements and textures are joined together. It is as these movements cohere, that they afford a "standing-within stillness," that rest which structures movement. It is this coherence, moreover, which constitutes the artwork's "jointure of the shining of truth."

\section{THE WAY-MAKING MOVEMENT}

In both "The Origin of the Work of Art" and "Anaximander's Saying," the term Fuge is employed as a jointure through which the limits of a being's entry into appearance are fixed and the being can appear "as" the being it is. For both, Fuge is thematized as a movement, either to be thought in terms of the "strife" of earth and world or as the construction of a "while" in which beings disclose themselves in a temporally bounded presence; for both, its movedness issues from the countermovements between presencing and absencing. Both, finally, align the "joining" of Fuge with logos. The artwork's engagement with its work-material was described as a "self-surpassing gathering," whilst in "Anaximander's Saying" Heidegger indicates an intimate relation between Fuge and the logos that "gathers" into a "tarrying presence."27 
Both the "jointure" of entities into presence and the gathering of logos are considered as modes of articulation: bringing entities into an intelligible whole through differentiating them. But if jointure and logos trace similar movements, then only logos is endowed with linguistic valence. In this next section, I wish to probe the movedness of what Heidegger identifies within language itself.

There is a danger in aligning Heidegger's thinking of logos too closely with "language" as a semantic-syntactic system. In Being and Time he proposed the existential of "discourse" as a translation for logos, the Greeks having "no word for "language." 28 Later he repudiated the focus on discourse as existential, as it turned language into "an activity of man" rather than attending to its "linguistic essence"; ${ }^{29}$ and in the 1939 Aristotle lecture (one of the key texts in his interpretation of logos as "gathering") he says: "Of itself legein has nothing to do with saying and with language," but rather describes "the original and fundamental relation to beings." ${ }^{30}$ In short, Heidegger's concern is primarily with the disclosive function of logos, and not the specificities of written or spoken utterance.

However, we can also read a more tempered account of the relation between verbal language and logos running throughout his work. In Being and Time, talking of the movement from the discoveredness of the world into linguistic meanings (Bedeutungen), he says: "The meaningful whole of intelligibility is put into words [Wörter]. To meanings, words accrue [Den Bedeutungen wachsen Worte zu]. But word-things do not get supplied with meanings." 31 What is striking here is not only that he uses a figure of accrual or growth [wachsen... zu] to describe meaning production, but that the growth happens within the words themselves, as a group of lexical items, Wörter, "grows" into the Worte of meaningful verbal comportment. ${ }^{32}$ And moments later Heidegger will argue that discourse can "make known" and "indicate" Dasein's stateof-mind through the "intonation, modulation, the tempo of talk," that is, the prosodic coloration of words. ${ }^{33}$ In both instances, verbal language is approached in terms of movement: on the one hand its "growth" into meaning, on the other the shape a phrase traces (intonation and 
modulation) and its accelerations and decelerations (tempo). But this poses a problem, as it is not clear how these movements interact with the temporality specific to discourse as "presencing." It seems, even, as if there are two incompatible notions of language at work in $B e$ ing and Time, which furnish highly divergent experiences of time. We find something similar in his later writing when he insists that verbal language should be understood as a "sounding word," anterior to the distinction between sound and sense. The basis of this claim is that it "is just as much a property of language to sound and ring and vibrate, to hover and to tremble, as it is for the spoken words of language to carry a meaning." ${ }^{34}$ Not only does this mean that prosodic features of verbal language cannot be entirely dismissed from the gathering of logos; it also means that there is a prosodic movedness of language independent of the gathering movement that brings beings into presence.

How do these two movements interact? To see this we should turn to yet another kind of movement by which Heidegger thematizes language: the Swabian archaism Be-wëgung, the movement that sets language "on its way." "The Way to Language" is organized around the "guideword": "to bring language to language as language." ${ }^{35}$ At first, Heidegger presents this as a challenge for thinking: how can we say something about language when our means to do so are themselves linguistic? And how can we speak about language in its "linguistic essence" - bringing language to language as language - rather than as a human activity (be it expression, representation, or communication), despite the fact that talking and thinking are themselves human activities? Heidegger wishes to ask what a non-human linguistic essence might be, and to this end he sketches the relation between an originary "Saying" [Sagan], which functions as a pre-verbal opening of intelligibility, and human verbal comportment [Sprechen]. If this would appear to mimic the structure of "ontological difference," we should note that Heidegger's interest is in the "unifying element" through which these two apparently opposed poles are bound together into one; instead of "saying" being the substrate of "speech," they are two moments within language, which meet when, as his famous guideword has it, "language speaks." 
This endows the phrase "to bring language to language as language" with a deeper significance: the "bringing" by which "saying" enters "speech" might offer the key to what "language" itself is. But this requires that there be a "unifying element" that joins together the originary articulation of "saying" with human speech. This will join together speech with both the possibilities that belong to speech, and the unspoken that bounds it. In his first attempt to grasp this unifying element, he sketches "the adjoinment [Gefüge] of a showing in which are joined [verfugt] the speakers and their speaking, the spoken and its unspoken out of the to-be-spoken. ${ }^{136}$ As with ecstatic temporality, Heidegger conceives of this unspoken as a double absence. This adjoinment will characterize what he subsequently names Sage: that element which unifies both the originary saying and human speech as features of language. But the "adjoinment" also pre-figures his final claim about how language is set on its way. Sage can only unify "saying" and "speech" if these two are appropriate for, and appropriable by, one another. He thus concludes: "Ereignis gathers together the design of saying [Sage] and unfolds it into the structure [Gefüge] of a manifold showing." ${ }^{.37}$ Ereignis, as a way-making movement, gathers language into a unified whole [Sage], so that it might gather beings into presence. Whence final revision of the guideword: "The way-making movement [Be-wëgung] brings language (linguistic essence) as language (Sage) into language (the sounding word). ${ }^{\prime 38}$ The way-making movement is not simply $k i$ netic, but, as Thomas Sheehan has observed, dynamic. ${ }^{39}$

What relation does this way-making movement bear to the prosodic movement of speech? In discussing the "site" of Trakl's poetry in the 1953 lecture, Heidegger hints at a response. The distinction between the "site of Trakl's poetry" [das Gedicht], that one poetic statement which binds all of Trakl's poetry together as a singular oeuvre, and the individual poems [Dichtungen] that make up his poetic output, is akin to that between "saying" and "speech." Neither individually nor as a totality do the Dichtungen articulate this statement completely in and of themselves; rather, we must trace within the poems a shared source out of which they arise, a source which continually pervades and 
animates the poems, and towards which they continually signal, even if only obliquely. Here I reproduce in full the passage cited partially in the introduction.

From the site of the poem there rises the wave that in each instance moves his Saying [Sagen] as poetic. But that wave, far from leaving the site behind, in its rise causes all the movement of Saying [Bewegen der Sage] to flow back to its ever more hidden source. The site of the poem, as the source of the animating wave, holds within it the veiled essence of what - to metaphysicalaesthetic representation - can at best appear as rhythm.

To trace the originary site out of which the poems stem requires that we grasp the animation underlying each poem; not only the wave upon which the poems flow, but the source of that wave - what first endows the poems with their animation. The movement of saying into speech is thematized in the same way as in "The Way to Language." There Sage transports the pre-verbal Sagen into the verbal Sprechen of the poem. Yet here it attains a specifically rhythmic valence: what "rhythm" would reveal is the very impulse into animation that lies within Sage.

But the precise role of prosody in Heidegger's argument (what he here terms "rhythm") is somewhat ambiguous. In his seminal essay on this topic, David Farrell Krell noted that the animating wave concerns "the peculiar binding power of language," a power which lies "beyond the mere linkage of syllables, or even of words and things, a binding power beyond both 'naming' and 'predicating." "40 Krell thus summarizes: "Rhythm has essentially nothing to do with the conformity of spoken or written language to inherited standards of measure and versification. It does have to do with the intrinsic motion and animation of language as such." ${ }^{41}$ But can the two be so neatly separated? That is, if "the source of the animating wave" can "best appear as rhythm" to "metaphysical-aesthetic representation," then in order to grasp this animation of language from within the epoch of metaphysics, we should attend to the poem's rhythm. Throughout his work Trakl 
employs meter and rhyme, extracting the sounds of words and syllables from their sense in order to create sonorous patterns. He too is confined within that "notion of language that has prevailed for thousands of years." Nevertheless, Heidegger suggests, these same rhythms will allow his poems to bear witness to the animation of language that pervades them and yet withdraws from their grasp.

This would mean that the poem's "linkage" of accentual feet would render manifest an anterior binding power of language. The poem's prosodic rhythms, in other words, become a point at which "metaphysical-aesthetic representation" exceeds its own representation. But it also means that at work in the poem will be two competing, and incompatible, experiences of movement: as it were rhythm and prosody. This recalls our observation about the two competing temporalities at work in the fugue itself: the series of "nows" of its time signature, and the entry of each instance of each voice into the "while" of polyphonic texture. Might these two diverging experiences of movement inflect not only Heidegger's exposition of poetic rhythm, but also the way that he reads poetic rhythms? This will be the topic of the final section.

\section{RHYTHM AND PROSODY}

Heidegger, notoriously, rarely discusses "form" in his readings of poetry; and yet there are some powerful exceptions to this rule. I will focus on two of them, twenty years apart. The first, from the Introduction to Metaphysics, is of the first choral ode from Sophocles' Antigone; the second is the reading of George's "In stillste ruh," whose "rhythm" of tropes is portrayed as a "fugue." Sophocles portrays man as the "most uncanny" [das Unheimlichste], insofar as he is being torn from the earth that would otherwise be "home." Heidegger observes:

The ode ... sings of breaking forth upon the groundless waves, of giving up firm land. This breakaway does not take place upon the cheerful smoothness of gleam-

ing water but amid the winter storm. The saying of this breakaway is situated in the law of motion of the 
word- and verse-structure [das Bewegungsgesetz der Wort- und Versfügung], just as the chorei in verse 336 is placed at the point where the meter $[$ Versma $\beta]$ shifts. $^{42}$

A few minutes earlier, Heidegger had read the ode aloud in the Greek, so that his audience would have heard the metrical shift for themselves. ${ }^{43}$ It is immediately striking that this shift is considered not simply to emphasize or qualify the meaning, nor to heighten our attentiveness to what is said, nor "echo" its sense; rather, it changes quite fundamentally the meaning of the word chorei. In the opening translation, chorei is given as kreuzt (rendered by Polt and Fried as "cruises" ${ }^{44}$ ), but after attending to its metrical position, Heidegger can continue:

[Man] gives up the place, he heads out-and ventures to enter the superior power of the sea's placeless flood. The word stands like a pillar in the construction of these verses. ${ }^{45}$

"Like a pillar," the word stands at rest and supports the weight of all that surrounds it. The resemblance to the temple in "The Origin of the Work of Art" (which he was working on at the same time), whose self-subsistence lies in its standing there in a repose that structures the relations around it, is striking. In both, we encounter an "inner concentration" which, far from indicating an absence of movedness, constitutes its nodal point. The shift that takes place on the word chorei might at first advertise itself as a metrical feature, but it subsequently reaches beyond its local metrical function to render manifest the "law of motion" governing the meter as a whole. This moment is what Heidegger in "Origin" termed the artwork's Gestalt: a moment of coherence where the work's countermovements are joined together in agitated stillness. The ode's prosody, it would seem, can use this moment of dissonance or transformation to grasp its own movedness.

In the reading of Sophocles' ode, Heidegger appeals to a metrical feature but does not ask what it is about the meter that allows it to transform the meaning of the strophe as a whole. When he comes to discuss "In stillste ruh," the question of rhythm as a jointure becomes the center of his analysis, but in so doing the account of rhythm comes 
to be troubled by the poem he reads. "In stillste ruh" itself probes the relation between rest and movement, as its eponymous rest is broken by "a sight which / With undreamed terror / Troubles the secure soul."

In stillste ruh

Besonnenen tags

Bricht jäh ein blick

Der unerahnten schrecks

Die sichre seele stört

So wie auf höhn

Der feste stamm

Stolz reglos ragt

Und dann noch spät ein sturm

Ihn bis zum boden beugt:

So wie das meer

Mit gellem laut

Mit wildem prall

Noch einmal in die lang

Verlassne muschel stößt.

In stillest rest

Of a musing day

Suddenly breaks a sight which

With undreamed terror

Troubles the secure soul

As when on the heights

The solid stem

Towers motionless in pride

And then late a storm

Bends it to the ground: 
As when the sea

With shrill scream

With wild crash

Once again into the long

Abandoned shell thrusts ${ }^{46}$

George's and Heidegger's thematization of movement and rest seem at first blush diametrically opposed. For George, the destruction of stillness would evoke the vulnerability of man faced with nature; for Heidegger, the poem successfully embodies a resting-within-itself. We might be tempted to say, as Paul de Man did of Heidegger's Hölderlin's readings, that George "says exactly the opposite of what Heidegger makes him say." "47 Yet Heidegger's central observation about the poem's compositional structure identifies a current within the poem that would counter this first interpretation. The colon at the end of the second stanza draws the second "As when" back to the first stanza. As a result, the poet, bent "to the ground as the storm bends the tree" in the second stanza, becomes "open" for the third stanza, where "the sea thrusts its unfathomable voice into the poet's ears which are called 'the long abandoned shell." 48 The third stanza, Heidegger argues, has engendered an openness to the world (somewhat akin to Dasein's "resolve" in Being and Time) in which the poem's "rest" is ultimately restored. Within the argument of Heidegger's reading, this shift is crucial: the openness the poem engenders will permit the "renunciation" that George, in "Das Wort," searches after.

But what of the "rhythmic" aspect of this poem? In the introduction I noted that situating the poem's rhythm in its tropological movement can be read as a denigration of the literary-critical category of prosody; but prosody cannot be so easily supressed. Heidegger enumerates the poem's figures thus: Sichre Seele, jäher Blick, Stamm und Sturm, Meer und Muschel; the pattern of two stressed syllables separated by one unstress mimics, and even condenses, the halting syncopations through which the poem both sets up a forward motion and presses back in on itself. ${ }^{49}$ Indeed, in order to retain this pattern, Heidegger undoes the contraction of jäher into jäh, and turns it from an adverb describing 
the "break" into adjective describing "sight." Heidegger's adherence to the poem's prosodic movement would distort its grammatical movement; contracting jäher into jäh might reproduce the regularity of the poem's prosody but, rendering an adverb an adjective, it imposes upon the poem a grammatical stasis. In addition to reading "rest" back into the poem through this openness to the world, his enumeration of the poem's figural movement brings its prosody and grammar to "rest."

The power of this particular reading lies not simply in its being a compelling exegesis of the poem, but in its performing a compelling encounter with the poem. And moreover, this encounter with the poem is prosodic. The "renunciation" the poem engenders through its openness, Heidegger concludes, is "no refusal of a claim but the transformation of the saying into the almost concealed roaring songlike echo of an unsayable Saga [die Wandlung des Sagens in den fast verborgen rauschenden liedhaften Widerklang einer unsägliche Sage]." "The poem has become nothing less than an allegory for the movement from the pre-verbal Sagen into the poem's speech; in its rhythmic jointure, it renders audible the Sage that joins the two together. Just as in the programmatic discussion of Trakl's "poetic site," this movement into speech is experienced as rhythm - but here it has been internalized into Heidegger's own rhythms. Earlier we noted how Heidegger's writing echoed the ebb and flow of George's stress-unstress syncopations; here, by contrast, we encounter a near-paratactic accumulation of adjectives, culminating in an almost "dactylic" progression of the cadence - rauschenden liedhaften Widerklang einer unsäglichen Sage - whose prosodic overflow seems like a release of the tension the poem had built up. ${ }^{51}$ At this crucial juncture, Heidegger's writing is remarkably unlike George's poem. The poem's kinesis, then, its "joining rest," plays itself out through the counterpoint of George's clipped dimeters and Heidegger's dactylic overflow.

Heidegger's reading of George's "fugal" rhythms involves him in a fugal interaction between the movement he wishes to trace from Sagen to Sprechen and the prosodic movement that marks his encounter with the poem. In "Origin" Heidegger argues that, for the work to remain at work requires that the artwork be taken up by its "preservers," who 
"stand within the openness of beings that happens in the work." 52 It is precisely such a preservation that is taking place in Heidegger's prosodic encounter with "In stillste ruh," and if this affords a momentary glimpse of "the almost concealed roaring songlike echo of an unsayable Saga," then it is precisely as the prosodic encounter exceeds itself and opens up a rhythmic jointure binding the two. But this also means that, despite Heidegger's somewhat patrician disdain for literary criticism, the categories through which literary critics conceive of rhythm become central to our grasping the originary movedness that George's poem would engender. Prosody is dynamized, not only in that it ceases to be the mere patterning of accents and syllables, but also in that more precise sense in which Heidegger translates dynamis: it sets thinking on its way. 


\section{Notes}

$1 \quad$ Unterwegs zur Sprache, 230-1 = On the Way to Language, 149; tm.

2 Unterwegs zur Sprache, $18-19=$ Poetry Language Thought, 193.

3 See his discussions of Aristotle's De Interpretatione in "The Nature of Language" and "The Way to Language," Unterwegs zur Sprache, $205=$ On the Way to Language, 98; Unterwegs zur Sprache, 244-5 = On the Way to Language, 115 .

4. Unterwegs zur Sprache, $38=$ On the Way to Language, 16o; tm.

5 In this, I am broadly following the "paradigm shift in Heidegger research" proposed by Thomas Sheehan; see Thomas Sheehan, "On Movement and the Destruction of Ontology," in Man and World, 64:4 (Oct 1981): 534-542, and most recently, "Astonishing! Things Make Sense!" in Gatherings: The Heidegger Circle Annual, I (2011): 1-25.

6 Sein und Zeit, $4{ }^{20-4,27}=$ Being and Time (trans. Macquarrie and Robinson), 473-4,80.

7 GA 9: 337 = Pathmarks, 204 .

8 Sein und Zeit, 159 = Being and Time, 201.

9 Holzwege, $3^{29}=$ Off the Beaten Track, 269.

$10 \quad$ Holzwege, $339=$ Off the Beaten Track, 277.

11 Holzwege, 328-329 = Off the Beaten Track, 268-269.

12 Sein und Zeit, $163=$ Being and Time, 207.

13 Der Satz vom Grund, $87=$ The Principle of Reason, 47.

14. Holzwege, $37=$ Off the Beaten Track, 26 .

15 Holzwege, 54 = Off the Beaten Track, 40.

16 Holzwege, 37-8 = Off the Beaten Track, 26-7.

17 Holzwege, $35=$ Off the Beaten Track, 24.

18 Holzwege, 37-8 = Off the Beaten Track, 26-7.

19 I take this to be the central point of Richard Polt's "Meaning, Excess, and Event", in Gatherings: The Heidegger Circle Annual, I (2011): 26-53. 
20 In the Aristotle lecture three years later, Heidegger will offer Gestalt as a translation for eidos; see GA 9: 344-346 = Pathmarks, 210-211.

23 Sheehan, "On Movement and the Destruction of Ontology," $53^{8}$.

24. Cézanne painted Vallier on several occasions late in his life. Julian Young takes the painting in question to be one of the 1906 versions, which is characterized by its light colours including patches of white to endow it with an unfinished quality (it was indeed one of the final paintings he completed before his death that year) and make it resemble the watercolour sketches he also made; see Julian Young, Heidegger's Philosophy of Art (Cambridge: Cambridge University Press, 2001), 153ff. However, the earlier paintings of Vallier, one of which dates from 1902 and another of which was being worked on over a long period up until his death, aim to capture the dark weariness of Vallier as my brief description does above. My reasons for opting to read Heidegger's poem in terms of this poem are double: firstly, because its pathos seems far more in keeping with Heidegger's tastes, as they are expressed in his discussion of Van Gogh's "peasant shoes"; secondly, because these are the paintings where an "in-standing stillness" really seems to be at issue.

25 Holzwege, $3^{8}=$ Off the Beaten Track, 27.

26 GA 13: 223. I would normally translate "inständig" by "inward"; the clunkiness of the proposed translation comes from the desire to retain the literal sense of standing-within, which is crucial to the stillness of the hermetic artwork from "Origin" onwards.

27 Holzwege, 340 = Off the Beaten Track, 278. Indeed, just before he embarks on his reading of dike, Heidegger says that the "fundamental words" of dike, tisis, and adikia, must be understood in terms of logos, aletheia, and phusis, "words which are thought from out of the experience of presencing" (Holzwege, $325=$ Off the Beaten Track, 265). 
28 Sein und Zeit, ${ }_{165}=$ Being and Time, 209 .

29 Unterwegs zur Sprache, 14 = Poetry Language Thought, 190.

30 GA 9: $35^{\circ}=$ Pathmarks, 213-4.

$3^{1} \quad$ Sein und Zeit, $161=$ Being and Time, 204; tm.

$3^{2}$ Both Jan Aler and Charles Guignon offer powerful discussions of this moment in Heidegger's account of language; see Jan Aler, "Heidegger's conception of language in Being and Time" in Macann (ed.), Martin Heidegger: Critical Assessments, vol.4 (London: Routledge, 1992), 28, and Charles Guignon, Heidegger and the Problem of Knowledge (Indianapolis: Hackett, 1983), $116 \mathrm{ff}$.

Sein und Zeit, $162=$ Being and Time, 205.

34. Unterwegs zur Sprache, $205=$ On the Way to Language, 98.

35 Unterwegs zur Sprache, 24,2 = On the Way to Language, 112 (I have changed Hertz's translation so as to follow Heidegger's formulation more closely).

$3^{6}$ Unterwegs zur Sprache, $25^{2}=$ On the Way to Language, 121.

37 Unterwegs zur Sprache, $259=$ On the Way to Language, 128.

38 Unterwegs zur Sprache, $261=$ On the Way to Language, 130.

39 Thomas Sheehan, "On the Way to Ereignis: Heidegger's Interpretation of Physis," in Hugh J. Silverman, John Sallis, and Thomas M. Seebohm (eds.), Continental Philosophy in America (Pittsburgh: Duquesne University Press, 1983), 131-164.

4. David Farrell Krell, "The Source of the Wave: Rhythm in the Languages of Poetry and Thinking," in Lunar Voices: Of Tragedy, Poetry, Fiction, and Thought (University of Chicago Press, 1995), 65 .

4.1 Krell, "The Source of the Wave," 60.

$4^{2}$ Einführung in die Metaphysik, $118=$ Introduction to Metaphysics, 164; tm.

43 Einführung in die Metaphysik, 112 = Introduction to Metaphysics, 156 .

44. Einführung in die Metaphysik, 112 = Introduction to Metaphysics, 156 . 
45 Einführung in die Metaphysik, $118=$ Introduction to Metaphysics, 164 .

${ }_{46} 6$ Unterwegs zur Sprache, 229-30 = On the Way to Language, 148; tm.

47 Paul de Man, "Heidegger's Exegeses of Hölderlin," in Blindness and Insight: Essays in the Rhetoric of Contemporary Criticism, edited by Wlad Godzich, second edition, (London: Methuen, 1983), 254-5. De Man continues: "it is already a major achievement to have, in a dialogue of this sort, the two interlocutors manage to speak of the same thing."

${ }_{4} 8$ Unterwegs zur Sprache, $23_{1}=$ On the Way to Language, 149.

49 Somewhat fortuitously, the English translation of 'sudden sight' for jäher Blick provides an extra alliterative pair.

50 Unterwegs zur Sprache, 231 = On the Way to Language, 150.

$5^{1} \quad$ Krell, discussing a passage from 'Why Poets?' (Unheil also Unheil spurt uns das Heile. Heiles er winkt rufend das Heilige. Heiliges bindet das Göttliche. Göttliches nähert den Gott), speaks of Heidegger's "strongly rhythmical line, which can be scanned as dactylic tetrameter and trimeter" ("The Source of the Wave," 72).

$5^{2}$ Holzwege, $55=$ Off the Beaten Track, ${ }_{41}$. 